Jurnal Pemikiran \& Penelitian Psikologi

\title{
PSIKOLOGIA
}

p-ISSN: $185-0327$

e-ISSN: 2549-2136

www.jurnal.usu.ac.id/psikologia

\section{GAMBARAN KUALITAS HIDUP PADA WANITA DEWASA AWAL PENDERITA KANKER PAYUDARA}

\section{THE DESCRIPTION OF QUALITY OF LIFE OF EARLY ADULTHOOD WOMAN WITH BREAST CANCER}

Rina Nurul Muslimah, Ade Rahmawati Psikologia: Jurnal Pemikiran \& Penelitian Psikologi

Tahun 2018, Vol. 13, No. 3, hal.142-152

Artikel ini dapat diakses dan diunduh pada:

www.jurnal.usu.ac.id/psikologia

\section{Dipublikasikan oleh:}

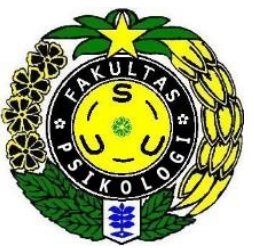

Fakultas Psikologi

Universitas Sumatera Utara

Jl. Dr. Mansyur No. 7 Medan. Telp/fax: 061-8220122

Email: psikologia@usu.ac.id 


\title{
GAMBARAN KUALITAS HIDUP PADA WANITA DEWASA AWAL PENDERITA KANKER PAYUDARA
}

\author{
Rina Nurul Muslimah dan Ade Rahmawati
}

Universitas Sumatera Utara

\begin{abstract}
ABSTRAK
Penelitian ini bertujuan untuk mengetahui gambaran kualitas hidup pada wanita dewasa awal penderita kanker payudara dengan menggunakan metode penelitian kuantitatif deskriptif. Populasi dalam penelitian ini adalah wanita dewasa awal berusia 18-40 tahun penderita kanker payudara di Kota Medan. Sampel dalam penelitian ini berjumlah 75 orang wanita dewasa awal penderita kanker payudara. Alat ukur yang digunakan adalah skala WHOQOL-BREF yang telah dimodifikasi oleh peneliti berdasarkan 4 aspek kualitas hidup, yaitu aspek physical health, aspek psychological, aspek social relationships, dan aspek environment. Hasil penelitian menunjukkan bahwa kualitas hidup pada wanita dewasa awal penderita kanker payudara berada pada kategori rendah. Berdasarkan aspek physical health, psychological, dan environment, kualitas hidup pada wanita dewasa awal penderita kanker payudara berada pada kategori rendah, sedangkan pada aspek social relationships berada pada kategori tinggi.
\end{abstract}

Kata kunci : kualitas hidup, kanker payudara, wanita dewasa awal

\section{THE DESCRIPTION OF QUALITY OF LIFE OF EARLY ADULTHOOD WOMAN WITH BREAST CANCER}

\begin{abstract}
S
The research aim to know the description of quality of life of early adulthood woman with breast cancerby using descriptive quantitative research method. The population of the research is early adulthood woman with breast cancer aged 18-40 year old in Medan. There are 75 early adulthood woman with breast cancer as samples in this research.For measuring instrument the researcher uses WHOQOL-BREF scale which has been modified by researcher based on 4 aspect of quality of life, physical health aspect, psychological aspect, social relationships aspect, and environment aspect. The research results shows that quality of life of early adulthood woman with breast cancerare in the low category. Based on physical health aspect, psychological aspect, and environment aspect,the quality of life of early adulthood woman with breast cancer are in the low category, while in social relationships aspect are in the high category.
\end{abstract}

Keywords : quality of life, breast cancer, early adulthood woman

*Korespondensi mengenai penelitian ini dapat dilayangkan kepada: psikologia@usu..ac.id
Rekomendasi mensitasi:

Muslimah, R.N., Rahmawati, A. (2018). Gambaran Kualitas Hidup pada Wanita Dewasa Awal Penderita Kanker Payudara. Psikologia :Jurnal Pemikiran dan 
Masa dewasa awal adalah masa peralihan dari masa remaja menuju masa dewasa. Wanita pada masa dewasa awal diharapkan dapat memainkan peran baru, seperti peran sebagai istri, orang tua, pencari nafkah, dan mengembangkan sikap, keinginan serta nilai - nilai baru sesuai dengan tugas-tugas perkembangannya. Menurut Hurlock (1999), tugas tugas perkembangan pada masa dewasa awal mencakup mulai bekerja, memilih pasangan hidup, mulai membina keluarga, mengasuh anak, mengelola rumah tangga, mengambil tanggung jawab sebagai warga negara dan mencari kelompok sosial yang menyenangkan. Menguasai tugas - tugas pada masa perkembangan selalu sulit, dan kesulitan ini meningkat apabila ada rintangan yang menghambat perkembangan seseorang.

Salah satu rintangan yang menghambat penguasaan tugas perkembangan masa dewasa awal adalah hambatan fisik (Hurlock, 1999). Hambatan fisik tersebut dapat berupa cacat fisik ataupun penyakit yang berkepanjangan. Wanita sering mengidap berbagai penyakit selama masa hidupnya, salah satunya adalah kanker payudara (Matlin, 2008). Kanker payudara adalah tumor ganas yang menyerang jaringan payudara, dimana jaringan payudara tersebut terdiri dari kelenjar susu (kelenjar pembuat air susu), saluran kelenjar (saluran air susu) dan jaringan penunjang payudara (Mardiana, 2007). Di Indonesia, diperkirakan terdapat 100 penderita baru untuk setiap 100.000 penduduk per tahun di Indonesia, dan angka kematian yang disebabkan oleh kanker payudara menduduki urutan keenam dari seluruh kematian di Indonesia
(Mohamad, 1997). Di Indonesia, masalah kanker payudara menjadi lebih besar karena lebih dari $70 \%$ penderita datang ke pelayanan kesehatan pada stadium yang sudah lanjut. (Saryono, 2008).

Wanita yang mengidap kanker payudara pada stadium dini maupun stadium lanjut dapat menjalani pengobatan medis untuk mengobatinya. Wanita yang menjalani pengobatan kanker payudara memiliki reaksi yang berbeda-beda. Terdapat ketidakstabilan yang besar pada emosi mereka dari hari ke hari (Matlin, 2008). Menurut Taylor (1999), pada wanita penderita kanker payudara yang menjalani pengobatan mastektomi, akan muncul gejala psikologis tertentu seperti depresi, stres, kecemasan, dan masalah-masalah psikologis lainnya. Pengobatan kemoterapi dan terapi radiasi juga dapat memberikan dampak negatif bagi psikologis penderita kanker payudara yang menjalaninya.

Bagi penderita penyakit kronis seperti kanker, ancaman bagi kualitas hidupnya adalah tekanan emosional yang serius, yang sebagian besar terdapat dalam bentuk depresi dan kecemasan. Kualitas hidup telah menjadi topik yang penting dalam hal perawatan medis karena kualitas hidup dapat menurun ketika individu terkena penyakit dan sakit dalam waktu yang lama, serta kualitas hidup dapat menjadi pertimbangan untuk pencegahan pada saat sebelum dan sesudah penyakit muncul (Sarafino, 2011). Penelitian yang dilakukan oleh Nurachmah (1999), menunjukkan bahwa penderita kanker payudara mengekspresikan ketidakberdayaan, merasa tidak sempurna lagi, malu dengan bentuk payudara, tidak bahagia, merasa tidak menarik lagi, 
perasaan kurang diterima oleh orang lain, merasa terisolasi, takut, berduka, berlamalama di tempat tidur, ketidakmampuan fungsional, gagal memenuhi kebutuhan keluarga, kurang tidur, sulit berkonsentrasi, kecemasan dan depresi.

Menurut WHO Quality of Life (WHOQOL) (dalam Rapley, 2003), menyatakan bahwa pengukuran kualitas hidup didasarkan pada 6 aspek yaitu aspek physical health, psychological, level of independence, social relationships, environment, dan spirituality/ religion/personal beliefs. Namun kemudian 6 aspek tersebut diperbaharui menjadi 4 aspek kualitas hidup (WHOQOL-BREF dalam Rapley, 2003) yang meliputi aspek physical health, psychological, social relationships, dan environment.

Dari pembahasan yang telah dipaparkan diatas, maka peneliti tertarik untuk melihat gambaran kualitas hidup pada wanita dewasa awal penderita kanker payudara. Peneliti tertarik untuk meneliti gambaran kualitas hidup pada wanita dewasa awal penderita kanker payudara berdasarkan empat dimensi dalam WHOQOL yaitu: dimensi kesehatan fisik, dimensi kesejahteraan psikologis, dimensi hubungan sosial, dan dimensi hubungan dengan lingkungan.

\section{Kualitas Hidup}

Menurut World Health Organization Quality of Life (WHOQOL) Group (dalam Rapley, 2003) mendefinisikan kualitas hidup sebagai persepsi individu tentang posisinya di kehidupan dalam konteks kebudayaan dan sistem nilai dimana mereka hidup, berhubungan dengan tujuan, harapan, ukuran, dan perhatian individu tersebut. Sedangkan Felce dan Perry (dalam Rapley, 2003) mendefinisikan kualitas hidup sebagai fenomena psikologis dimana kualitas hidup adalah keseluruhan kesejahteraan umum yang terdiri dari penjelasan objektif dan evaluasi subjektif dari kesejahteraan fisik, material, sosial, dan emosional bersama dengan tingkat pengembangan pribadi dan aktivitas yang mempunyai tujuan yang seluruhnya melalui pertimbangan nilai nilai pribadi individu.

\section{Wanita Dewasa Awal}

Hurlock (1999) menyatakan bahwa masa dewasa awal dimulai pada umur 18 40 tahun, saat perubahan - perubahan fisik dan psikologis yang menyertai berkurangnya kemampuan reproduktif. Santrock (2002) menyatakan bahwa masa dewasa awal adalah masa untuk bekerja dan menjalin hubungan dengan lawan jenis, terkadang menyisakan sedikit waktu untuk hal lainnya.

\section{Kanker Payudara}

Kanker adalah sebuah penyakit dari sel - sel dimana ditandai dengan penyebaran sel yang tidak terkontrol yang biasanya membentuk neoplasma ganas (Sarafino, 2011). Kanker payudara adalah pertumbuhan serta perkembangbiakan sel yang abnormal yang muncul pada jaringan payudara (Dewi, 2009). Menurut Luwia (2003), gejala kanker payudara pada tahap dini biasanya tidak menimbulkan keluhan. Satu - satunya gejala yang mungkin dirasakan pada stadium dini adalah benjolan kecil di payudara.

\section{METODE}

\section{Partisipan}


Partisipan dalam penelitian ini adalah wanita dewasa awal penderita kanker payudara di kota Medan sebanyak 75 orang dengan metode pengambilan sampel yang digunakan dalam penelitian ini adalah metode non probability sampling jenis accidental sampling. Karakteristik yang harus dipenuhi oleh partisipan adalah:

a. Wanita dewasa awal usia $18-40$ tahun yang menderita kanker payudara.

b. Sedang menjalani pengobatan medis kanker payudara

c. Menderita kanker payudara stadium IIB - IIIB

\section{Gambaran Umum Partisipan}

Subjek penelitian berjumlah 75 wanita yang merupakan penderita kanker payudara di Medan. Berdasarkan skala yang diberikan, diperoleh gambaran subjek penelitian menurut stadium kanker dan pengobatan medis.

Tabel 1. Gambaran Umum Subjek Penelitian Berdasarkan Stadium Kanker.

\begin{tabular}{ccc}
\hline $\begin{array}{c}\text { Stadium } \\
\text { Kanker }\end{array}$ & N & $\begin{array}{c}\text { Persentase } \\
(\%)\end{array}$ \\
\hline IIB & 40 & $53.3 \%$ \\
IIIA & 28 & $37.3 \%$ \\
IIIB & 7 & $9.3 \%$ \\
\hline
\end{tabular}

Tabel 2. Gambaran Umum Subjek Penelitian Berdasarkan Pengobatan Medi

\begin{tabular}{ccc}
\hline Pengobatan Medis & N & $\begin{array}{c}\text { Persentase } \\
\text { (\%) }\end{array}$ \\
\hline Mastektomi & 26 & $35 \%$ \\
Mastektomi dan & 46 & $61 \%$ \\
Kemoterapi & 3 & $4 \%$ \\
$\begin{array}{c}\text { Mastektomi, } \\
\text { Kemoterapi dan Terapi } \\
\text { Radiasi }\end{array}$ & & \\
\hline
\end{tabular}

\section{Alat Ukur}

Metode yang digunakan dalam pengumpulan data pada penelitian ini adalah metode self-reports. Sesuai dengan metode self-reports maka penelitian ini menggunakan skala kualitas hidup untuk memperoleh gambaran kualitas hidup pada penderita kanker payudara. Skala yang digunakan adalah terdapat empat aspek dari kualitas hidup, yaitu physical health (kesehatan fisik), psychological (psikologis), social relationships (hubungan sosial), dan environment (lingkungan). Skala ini menggunakan skala model Likert. Skala ini terdiri dari 5 pilihan jawaban yaitu Sangat Sesuai (SS), Sesuai (S), Netral (N), Tidak Sesuai (TS), dan Sangat Tidak Sesuai (STS).

\section{Uji Realibilitas dan Uji Validitas}

Uji realibilitas dan validitas menggunakan SPSS versi 17.0 for windows maka diperoleh reliabilitas dengan koefisien alpha keseluruhan aitem sebesar 0,962. Dari 60 aitem yang diuji coba terdapat 52 aitem yang valid dengan nilai $r$ yang bergerak dari 0,255 sampai 0,845. Sedangkan 8 aitem dinyatakan gugur.

\section{Teknik Analisa Data}

Data yang akan diolah yaitu skor minimum, skor maksimum, mean dan standar deviasi. Hadi (2000) menyatakan bahwa uraian kesimpulan dalam penelitian deskriptif didasari oleh data yang diolah tidak terlalu mendalam. Data yang berhasil dikumpulkan kemudian diolah dengan menggunakan bantuan program SPSS.

Uji Normalitas

Tabel 3. Uji Normalitas

\begin{tabular}{cccc}
\hline \multirow{2}{*}{ Variabel } & \multicolumn{3}{c}{ Kolmogorov-Smirnov } \\
\cline { 2 - 4 } & Statistic & $\mathrm{df}$ & Sig. \\
\hline $\begin{array}{c}\text { Kualitas } \\
\text { Hidup }\end{array}$ & .095 & 75 & .090 \\
\hline
\end{tabular}


Berdasarkan tabel 7, keseluruhan variabel penelitian terdistribusi normal ( $p \geq 0.05)$ dimana kriterianya menurut Hadi (2000) adalah apabila $\mathrm{p} \geq 0.05$ maka sebarannya dinyatakan normal dan sebaliknya, bila $\mathrm{p}<0.05$ maka sebarannya dinyatakan tidak normal. Dari data yang diperoleh pada tabel diatas menunjukkan subjek pada penelitian ini terdistribusi normal dimana $\mathrm{p} / \mathrm{sig}=.090$.

\section{HASIL}

Gambaran Kualitas Hidup pada Wanita Dewasa Awal Penderita Kanker Payudara

$$
\text { Hasil analisa deskriptif }
$$
menampilkan skor empiric dan skor teoritik kualitas hidup pada wanita dewasa awal penderita kanker payudara.

Tabel 4. Skor Empirik dan Skor Teoritik Kualitas Hidup pada Wanita Dewasa Awal Penderita Kanker Payudara

\begin{tabular}{ccccccccc}
\hline Variabel & \multicolumn{4}{c}{ Empirik } & \multicolumn{4}{c}{ Teoritik } \\
\hline $\begin{array}{c}\text { Kualitas } \\
\text { Hidup }\end{array}$ & Min & Maks & Mean & SD & Min & Maks & Mean & SD \\
\cline { 2 - 9 } & 97 & 197 & 145.83 & 28.75 & 52 & 260 & 156 & 34.667 \\
\hline
\end{tabular}

Selanjutnya, subjek digolongkan ke dalam 2 kategori yaitu tinggi dan rendah. Pengelompokan kualitas hidup pada wanita dewasa awal penderita kanker payudara dilakukan dengan pengkategorian subjek berdasarkan kategorisasi skor kualitas hidup sebagaimana yang tertera pada grafik berikut:

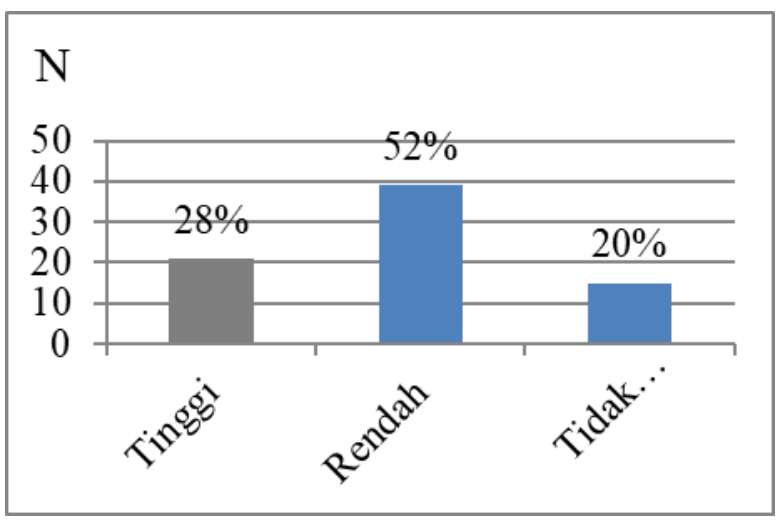

Gambaran Kualitas Hidup pada Wanita Dewasa Awal Penderita Kanker Payudara Berdasarkan Aspek Kualitas Hidup

Aspek Kesehatan Fisik

Tabel 5. Skor empirik dan skor teoritik kualitas hidup pada wanita dewasa awal penderita kanker payudara berdasarkan aspek kesehatan fisik

\begin{tabular}{ccccccccc}
\hline Variabel & \multicolumn{4}{c}{ Empirik } & \multicolumn{4}{c}{ Teoritik } \\
\hline $\begin{array}{c}\text { Aspek Kesehatan } \\
\begin{array}{c}\text { Fisik pada } \\
\text { Kualitis Hidup }\end{array}\end{array}$ & 18 & 46 & 31.27 & 7.431 & 12 & 60 & 36 & 8 \\
\hline
\end{tabular}

Pengelompokan kualitas hidup pada wanita dewasa awal penderita kanker payudara berdasarkan aspek kesehatan fisik dilakukan dengan pengkategorian subjek berdasarkan kategorisasi skor aspek kesehatan fisik, sebagaimana yang tertera pada grafik berikut:

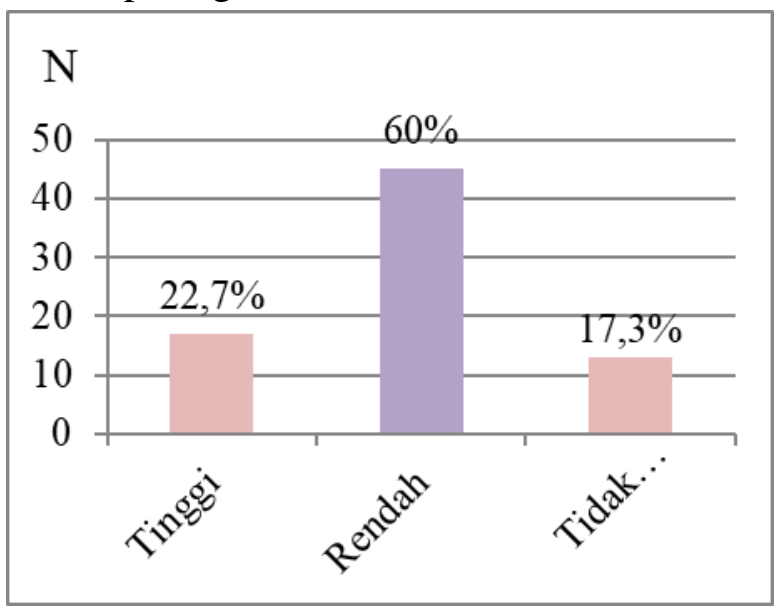




\section{Aspek Kesejahteraan Psikologis}

Tabel 6. Skor empirik dan skor teoritik kualitas hidup pada wanita dewasa awal penderita kanker payudara berdasarkan aspek kesejahteraan psikologis

\begin{tabular}{cccccccccc}
\hline Variabel & \multicolumn{4}{c}{ Empirik } & \multicolumn{5}{c}{ Teoritik } \\
\hline $\begin{array}{c}\text { Aspek Kesejahteraan } \\
\text { Psikologis pada } \\
\text { Kualitas Hidup }\end{array}$ & 20 & 49 & 32.88 & 8.018 & 12 & 60 & 36 & 8 \\
\cline { 2 - 8 } & & & & & & & & & \\
\hline
\end{tabular}

Pengelompokan kualitas hidup pada wanita dewasa awal penderita kanker payudara berdasarkan aspek kesejahteraan psikologis dilakukan dengan pengkategorian subjek berdasarkan kategorisasi skor aspek kesejahteraan psikologis, sebagaimana yang tertera pada grafik berikut:

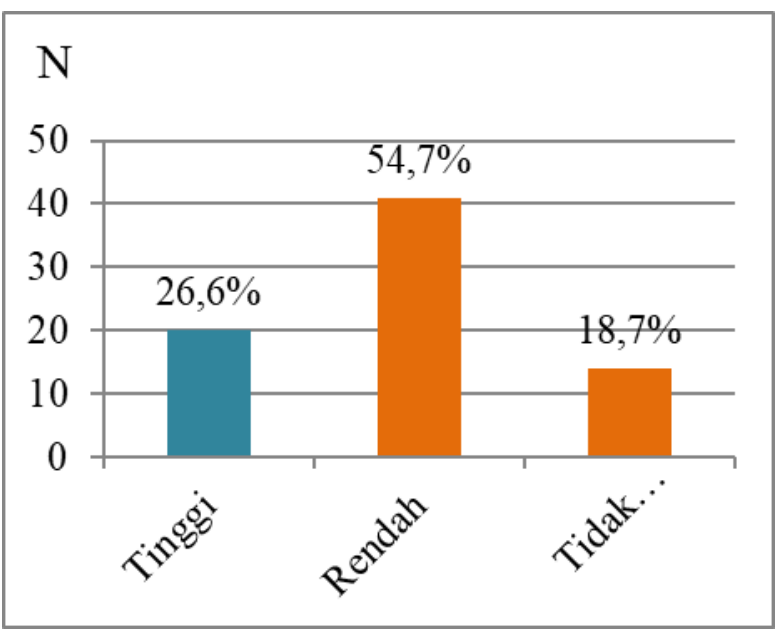

\section{Aspek Hubungan Sosial}

Tabel 7. Skor empirik dan skor teoritik kualitas hidup pada wanita dewasa awal penderita kanker payudara berdasarkan aspek hubungan sosial.

\begin{tabular}{ccccccccc}
\hline Variabel & \multicolumn{3}{c}{ Empink } & \multicolumn{4}{c}{ Teoritik } \\
\hline $\begin{array}{c}\text { Aspek Hubungan } \\
\begin{array}{c}\text { Sosial pada } \\
\text { Kulitias Hidup }\end{array}\end{array}$ & Min & Maks & Mean & SD & Min & Maks & Mean & SD \\
\hline
\end{tabular}

Pengelompokan kualitas hidup pada wanita dewasa awal penderita kanker payudara berdasarkan aspek hubungan sosial dilakukan dengan pengkategorian subjek berdasarkan kategorisasi skor aspek hubungan sosial, sebagaimana yang tertera pada grafik berikut:

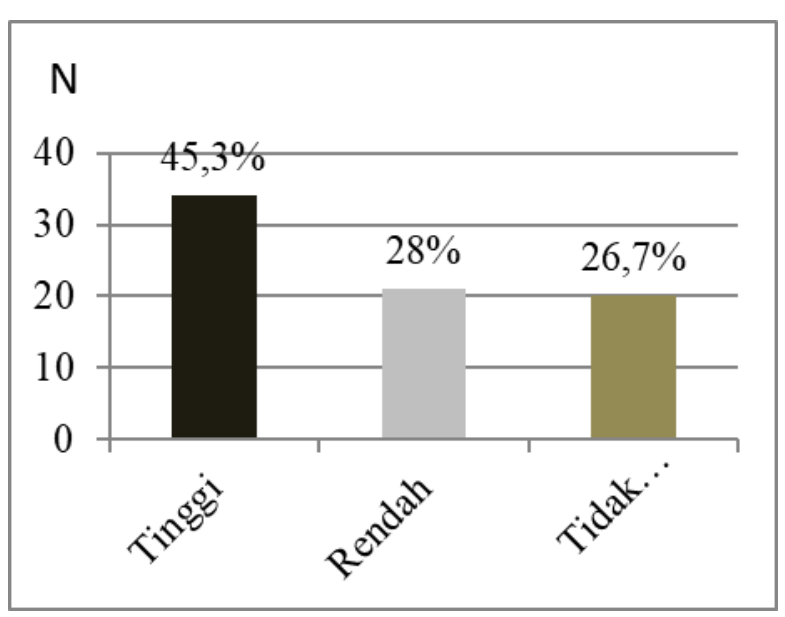

\section{Aspek Hubungan dengan Lingkungan}

Tabel 8. Skor empirik dan skor teoritik kualitas hidup pada wanita dewasa awal penderita kanker payudara berdasarkan aspek hubungan dengan lingkungan.

\begin{tabular}{ccccccccc}
\hline Variabel & \multicolumn{4}{c}{ Empirik } & \multicolumn{5}{c}{ Teoritik } \\
\hline $\begin{array}{c}\text { Aspek Hubungan } \\
\text { dengan Lingkungan } \\
\text { pada Kualitas Hidup }\end{array}$ & Min & Maks & Mean & SD & Min & Maks & Mean & SD \\
\cline { 2 - 9 } & & 41.13 & 8.565 & 15 & 75 & 45 & 10 \\
\hline
\end{tabular}

Pengelompokan kualitas hidup pada wanita dewasa awal penderita kanker payudara berdasarkan aspek hubungan dengan lingkungan dilakukan dengan pengkategorian subjek berdasarkan kategorisasi skor aspek hubungan dengan lingkungan, sebagaimana yang tertera pada grafik berikut: 


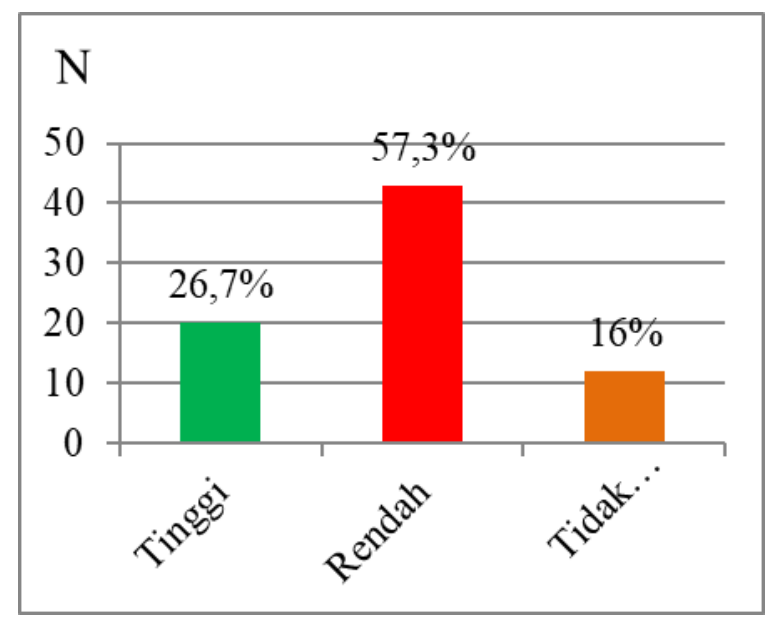

\section{DISKUSI}

Hasil penelitian yang diperoleh menunjukkan secara umum kualitas hidup pada wanita dewasa awal penderita kanker payudara pada penelitian ini termasuk dalam kategori rendah. Dari 75 subjek penelitian, sebanyak 39 orang (52\%) memiliki kualitas hidup yang rendah, 21 orang (28\%) memiliki kualitas hidup yang tinggi dan sebanyak 15 orang (20\%) tidak diklasifikasikan karena tujuan semula hanya memisahkan subjek ke dalam dua kategori.

Berdasarkan hasil pengukuran gambaran kualitas hidup pada wanita dewasa awal penderita kanker payudara pada penelitian ini diperoleh data kualitas hidup sebagian besar responden cenderung rendah, yaitu sejumlah 39 orang (52\%) dari 75 orang. Kualitas hidup yang rendah pada penelitian ini ditunjukkan dengan rendahnya kesehatan fisik, kesejahteraan psikologis, serta hubungan dengan lingkungan bagi para wanita dewasa awal penderita kanker payudara tersebut.

Hasil penelitian ini sejalan dengan penelitian yang dilakukan oleh Nurachmah (1999), dimana penderita kanker payudara mengekspresikan ketidakberdayaan, merasa tidak sempurna lagi, malu dengan bentuk payudara, tidak bahagia, merasa tidak menarik lagi, perasaan kurang diterima oleh orang lain, merasa terisolasi, takut, berduka, berlama-lama di tempat tidur, ketidakmampuan fungsional, gagal memenuhi kebutuhan keluarga, kurang tidur, sulit berkonsentrasi, kecemasan dan depresi, dimana dapat memicu penurunan kualitas hidupnya. Kroenke et al (dalam Avis et al, 2004) juga menemukan bahwa wanita dibawah 40 tahun dengan kanker payudara mengalami penurunan signifikan lebih besar pada peran fisik, nyeri tubuh, fungsi sosial, dan kesehatan mental, dimana pada penelitian ini keseluruhan subjek berada pada rentang usia 18 - 40 tahun. Rendahnya kualitas hidup pada penderita kanker juga dapat dipengaruhi oleh faktor yang beranekaragam, seperti gejala, jenis perawatan yang diperoleh pasien, status penampilan pasien, depresi, dan keyakinan spiritual (Kreitler et al, dalam Pradana, 2013).

Dalam penelitian ini, kualitas hidup pada wanita dewasa awal penderita kanker payudara juga diukur berdasarkan empat aspek dari kualitas hidup oleh WHOQOL (dalam Rapley, 2003), yaitu aspek hubungan sosial, aspek kesehatan fisik, aspek psikologis, , dan aspek lingkungan. Menurut WHOQOL (dalam Rapley, 2003), hubungan sosial mencakup relasi personal, dukungan sosial, dan aktivitas seksual. Dalam penelitian ini berdasarkan aspek hubungan sosial, subjek lebih banyak berada pada kategori tinggi yaitu sejumlah 34 orang $(45.3 \%)$. Hal ini dikarenakan mereka mendapat dukungan sosial dari keluarga dan teman terdekat. Hasil ini sesuai dengan pendapat yang disampaikan oleh Sarafino (2011) yaitu sumber utama dukungan sosial yang dibutuhkan oleh kebanyakan orang sakit biasanya berasal dari keluarga mereka. Teman dan tetangga 
juga ikut membantu memberikan dukungan sosial, dan penderita biasanya akan bergabung dengan kelompok dukungan yang memiliki masalah medis tertentu.

Tingginya dukungan sosial yang diterima subjek pada penelitian ini terkait dengan budaya kolektif pada masyarakat Indonesia. Hasil penelitian yang dilakukan oleh Sumantri \& Sumarsono (2007). Selalu ada orang lain di sisi manusia yang bersifat kolektif karena permasalahan satu orang adalah juga kepedulian bagi anggota lainnya. Dengan budaya kolektif yang ada pada masyarakat Indonesia, maka dukungan sosial yang diterima seseorang yang mengidap suatu penyakit akan tinggi karena mendapat dukungan dari keluarga dan teman - temannya.

Menurut WHOQOL (dalam Rapley, 2003), aspek kesehatan fisik mencakup aktivitas sehari - hari, ketergantungan pada obat - obatan, energi dan kelelahan, mobilitas, sakit dan ketidaknyamanan, tidur dan istirahat, serta kapasitas kerja. Dalam penelitian ini berdasarkan aspek kesehatan fisik, subjek lebih banyak berada pada kategori rendah, yaitu sejumlah 45 orang $(60 \%)$. Hasil penelitian oleh Avis et al (2004) juga menunjukkan bahwa wanita penderita kanker payudara memiliki kesehatan fisik yang rendah dimana terdapat symptom symptom yang intens akibat dari kanker yang dideritanya.

Aspek psikologis mencakup bodily image dan appearance; perasaan negative; perasaan positif; self-esteem; spiritual/ agama/keyakinan pribadi; berpikir, belajar, memori dan konsentrasi (WHOQOL, dalam Rapley, 2003). Dalam penelitian ini berdasarkan aspek psikologis, subjek lebih banyak berada pada kategori rendah, yaitu sejumlah 41 orang (54.7\%). Subjek mendapatkan kekuatan dan merasa lebih sehat walaupun tanpa obat, hal ini disebabkan karena adanya sugesti dalam diri individu tersebut untuk tetap sehat tanpa obat. Sebaliknya, ketika psikologis individu rendah maka ancaman bagi kualitas hidupnya adalah tekanan emosional yang serius, yang sebagian besar terdapat dalam bentuk depresi dan kecemasan (Sarafino, 2011).

Hubungan dengan lingkungan mencakup sumber finansial, kebebasan, keamanan dan keselamatan fisik; perawatan kesehatan dan sosial termasuk aksesbilitas dan kualitas; lingkungan rumah, kesempatan untuk mendapatkan berbagai informasi baru maupun keterampilan; partisipasi dan mendapat kesempatan untuk melakukan rekreasi dan kegiatan yang menyenangkan di waktu luang; lingkungan fisik; serta transportasi (WHOQOL dalam Rapley, 2003). Dalam penelitian ini berdasarkan aspek hubungan dengan lingkungan, subjek lebih banyak berada pada kategori yang rendah yaitu sejumlah 43 orang (57.3\%).

\section{KESIMPULAN}

1. Kualitas hidup pada wanita dewasa awal penderita kanker payudara lebih banyak berada pada kategori rendah, yaitu sebanyak 39 orang (52\%). Kualitas hidup yang rendah adalah dimana individu memiliki kesehatan fisik yang kurang baik, kurang memiliki kemampuan fisik untuk melakukan hal hal yang ingin dilakukan, memiliki pandangan psikologis yang negatif, sulit untuk berpartisipasi dalam kegiatan sosial dan rekreasi, dan berada dalam lingkungan yang kurang nyaman bagi dirinya. 
2. Berdasarkan aspek - aspek kualitas hidup, kualitas hidup pada wanita dewasa awal penderita kanker payudara pada aspek kesehatan fisik lebih banyak berada pada kategori rendah sebanyak 45 orang $(60 \%)$, dimana subjek sulit untuk beraktivitas, susah tidur, dan merasakan nyeri yang intens akibat penyakitnya. Berdasarkan aspek kesejahteraan psikologis subjek lebih banyak berada pada kategori rendah sebanyak 41 orang $(54,7 \%)$, dimana subjek memiliki perasaan negatif terhadap dirinya, dan kurangnya kepercayaan diri. Sedangkan berdasarkan aspek hubungan sosial subjek lebih banyak berada pada kategori tinggi sebanyak 34 orang $(45,3 \%)$, dimana subjek mendapat dukungan sosial yang baik dan tidak memiliki keluhan akan aktivitas seksual. Berdasarkan aspek hubungan dengan lingkungan subjek lebih banyak berada pada kategori rendah 43 orang sebanyak $(57,3 \%)$, dimana subjek tidak merasa nyaman dengan lingkungan rumah ataupun rumah sakit, serta sulit untuk melakukan kegiatan yang menyenangkan di waktu luang.

\section{SARAN}

\section{Saran Metodologis}

Berikut ini adalah beberapa saran metodologis yang penting untuk dipertimbangkan, yaitu:

1. Dikarenakan penelitian ini adalah penelitian deskriptif dengan variabel tunggal yaitu kualitas hidup, bagi peneliti yang berminat untuk mengembangkan penelitian kualitas hidup pada penderita kanker payudara ini lebih lanjut, hendaknya dapat menambah variabel yang dapat dikaitkan dengan kualitas hidup.
2. Dalam penyusunan alat ukur, sebaiknya lebih mempehatikan penyebaran aitem pada masing masing aspek dalam skala agar semuanya memiliki proporsi yang sama atau seimbang, dikarenakan proporsi aitem pada penelitian ini kurang seimbang.

3. Bagi peneliti selanjutnya yang tertarik untuk meneliti kualitas hidup terutama untuk penderita kanker payudara dapat dilakukan dengan metode kualitatif untuk memperoleh informasi yang lebih dalam dan memperjelas setiap respon dari sampel penelitian dengan teknik wawancara dan observasi karena penelitian ini menggunakan metode deskriptif yang didasari oleh data yang diolah tidak terlalu mendalam.

\section{Saran Praktis}

1. Berdasarkan hasil penelitian ini dimana pada aspek kesehatan fisik, kesejahteraan psikologis, dan hubungan dengan lingkungan berada pada kategori rendah, oleh karena itu disarankan bagi para wanita dewasa awal penderita kanker payudara dapat meningkatkan kualitas hidupnya dengan menerapkan gaya hidup yang sehat dengan mengonsumsi makanan yang sehat dan aktif bergerak, meminum obat dengan teratur, selalu berusaha berpikir positif, serta meluangkan waktu untuk melakukan kegiatan yang menenangkan diri di waktu luang.

2. Berdasarkan hasil penelitian ini dimana pada aspek kesehatan fisik, kesejahteraan psikologis, dan hubungan dengan lingkungan berada pada kategori rendah namun pada aspek dukungan sosial berada pada kategori tinggi, oleh karena itu 
disarankan bagi keluarga dari penderita kanker payudara agar dapat lebih memperhatikan kesejahteraan anggota keluarganya yang mengidap kanker payudara dengan lebih memperhatikan keteraturan jadwal minum obat penderita dan menjaganya agar tidak mudah lelah, memperhatikan kebersihan dan keamanan lingkungan sekitar tempat tinggal, tetap selalu memotivasi penderita, serta lebih sering mengajak penderita untuk melakukan kegiatan yang menyenangkan untuk mengisi waktu luang.

\section{REFERENSI}

Dewi, L (2009). Kanker Payudara, mendeteksi gejala dini, pencegahan dan pengobatan. Yogyakarta: Tugu Publisher.

Hurlock, E. B. (1999). Psikologi Perkembangan : Suatu Pendekatan Sepanjang

Luwia, M. (2003). Problematika dan keperawatan payudara. Edisi 1. Jakarta: Kawan Pustaka

Mardiana, L. (2007). Kanker pada wanita; pencegahan dan pengobatan dengan tanaman obat. Edisi 5. Jakarta: Panebar Swadaya

Matlin, M.W. (2008). The Psychology of Women. (6th edition). USA: Thomson Higher Education.

Mohamad, K. (1997). Ginekologi dan kesehatan wanita. Jakarta: Gaya Favorit Press

Nurachmah, E. (1999). Dampak kanker payudara dan pengobatannya terhadap Aspek bio-psiko-sosiospiritual klien yang berpartisipasi dalam kelompok pendukung. Jurnal Keperawatan Indonesia, Vol.II: hal
186-194. Jakarta: Universitas Indonesia

Rapley, M. (2003). Quality of Life Research: a critical introduction. London: Sage Publications

Rentang kehidupan, Edisi ke-5. Jakarta : Erlangga.

Santrock, J. W. (2002). Life Span Development. Perkembangan Masa Hidup. Jilid 2, Wisnu Chandra, (terjemahan). Jakarta: Erlangga.

Sarafino, P.E. (2011). Health Psychology; biopsychosocial interactions (7th Ed). USA: John Wiley \& Sons Inc.

Saryono (2008). Perawatan Payudara. Yogyakarta: Mitra Cendikia Press.

Taylor, S. E. (1999). Health psychology. (4th Ed.). Singapore: McGraw-Hill. 